\title{
Glaciological reconnaissance, mass balance measurements and mapping programmes in connection with Greenland hydropower
}

\section{Henrik Højmark Thomsen}

Glaciological field work and mapping programmes have been carried out in areas proposed for local hydropower projects.

\section{Glaciological reconnaissance}

Glaciological reconnaissance was carried out in the Angmagssalik area, East Greenland, and in areas around Jakobshavn, Christianshåb and Godhavn in West Greenland (fig. 38). Descriptions of the areas, based on studies of maps, aerial photographs and previous investigations are given in Weidick \& Thomsen (1983a).

Most of the areas have not previously been visited by GGU in connection with hydropower investigations. Because of the size and inaccessibility of the areas, the main part of the work was carried out by helicopter.

Possible investigation sites have been selected from a glaciological-hydrological and logistic viewpoint. Glacier margin positions have also been photodocumented and icedammed lakes recorded.

Fig. 38. Map of localities where glaciological reconnaissance has been carried out.

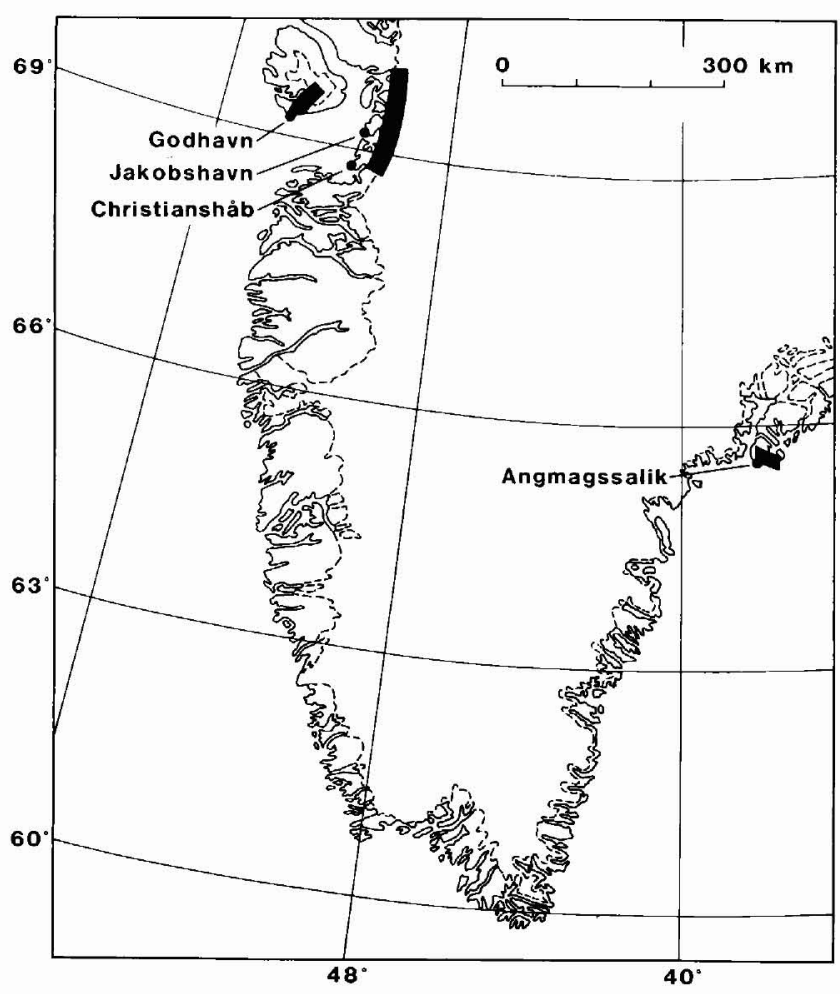




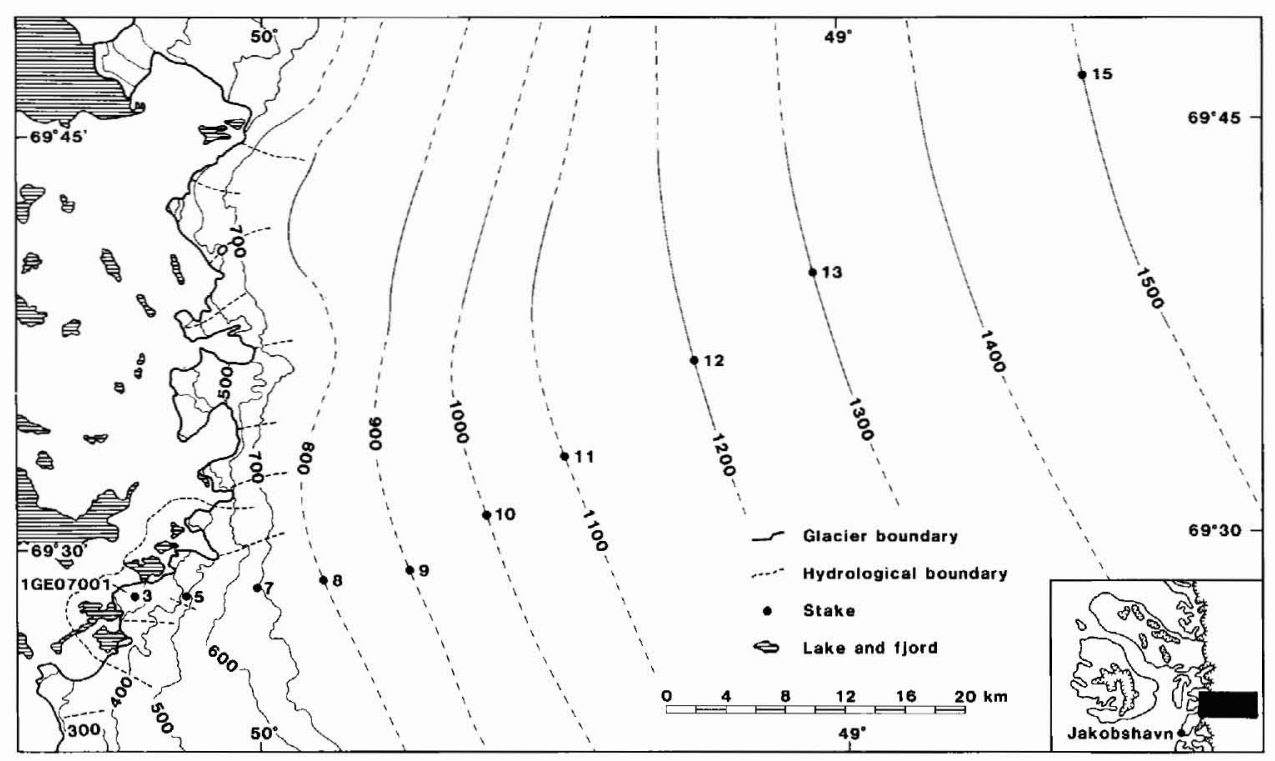

Fig. 39. Drainage basin at Pâkitsoq. Stakes drilled into the ice are shown. Contours in metres.

Angmagssalik area. Glaciers around Qordlortoq Sø in the southern part of Angmagssalik $\emptyset$ were photographed. The work was complicated by the extremely cloudy and snowy weather conditions at the time of the visit.

Near infra-red photographs of glaciers were also taken to try to separate different snow facies.

A small cirque glacier (inventory no. 3HH02003), lying about three hours walking distance from Angmagssalik town, would be suitable for mass balance measurements if necessary.

Jakobshavn and Christianshåb area. The margin of the Inland Ice from Eqip sermia (inventory no. $1 \mathrm{GF} 06001$ ) at $69^{\circ} 48^{\prime} \mathrm{N}$ down to Jakobshavn Isbræ (inventory no. 1GC06002) at $69^{\circ} 08^{\prime} \mathrm{N}$ was photographed to update the glacier registration in this area.

The big ice-dammed lake Tiningnilik located at the margin of the Inland Ice south-west of Christianshåb was visited. The tapping period is ten years according to written records and compilation of scattered information from aerial photographs and satellite images (Weidick \& Olesen, 1980; Weidick \& Thomsen, 1983a). By comparison with aerial photographs, the water level was found to be the lowest ever observed at the time of the visit (13th August 1983). The fall in water level from the maximum was $53 \mathrm{~m}$. The ice margin connected to the ice-dammed lake was photographed. The photographs were taken as normal $24 \times 36$ colour slides with stereo coverage to be used for later photogrammetric mapping on an alytical plotter installed at Institut for Landmåling og Fotogrammetri, Danmarks Tekniske Højskole. 
Fig. 40. Mass balance in relation to elevation on the Inland Ice at Pâkitsoq. I Transient balance (15th August 1982 - 12th May 1983). II Transient balance (12th May 1983 - 11th August 1983). III Annual balance (15th august $1982-11$ th August 1983).

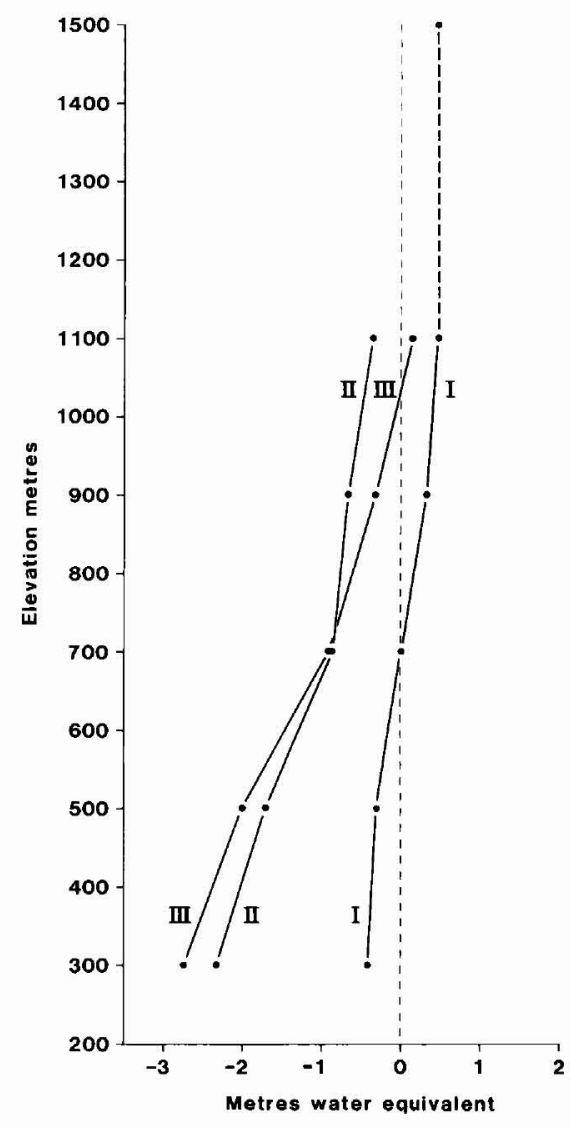

Godhavn Area. Glaciers in Blæsedalen, Brededal and Daugaard-Jensen Dal were photographed. Several sites were found to be suitable for glaciological investigations.

\section{Mass balance measurements in Pâkitsoq 1982/1983}

Stakes (nos 3, 5, 7, 9, 13 and 15) for measuring mass balance were drilled into the Inland Ice, at Pâkitsoq, north-east of Jakobshavn in August 1982 (fig. 39). The drainage basin and initial work at Pâkitsoq is described in Thomsen (1983a, 1983b).

The stakes were visited by helicopter on the 12th of May and on the 11th of August 1983 to measure the mass changes during the winter and summer period. One stake (stake 13) could not be found in May and two stakes (stakes 13 and 15) could not be found in August, probably due to faulty navigation. Three new stakes (stake 8,10 and 12) and a replacement of the last stake 13 were drilled in August 1983.

The winter snow cover on the ice was very patchy and was confined mainly to drifts in gullies and crevasses up to stake 5, while it was continuous from stake 7 . For instance, no winter snow was recorded around stakes 3 and 5 . The transient balance for the winter period 


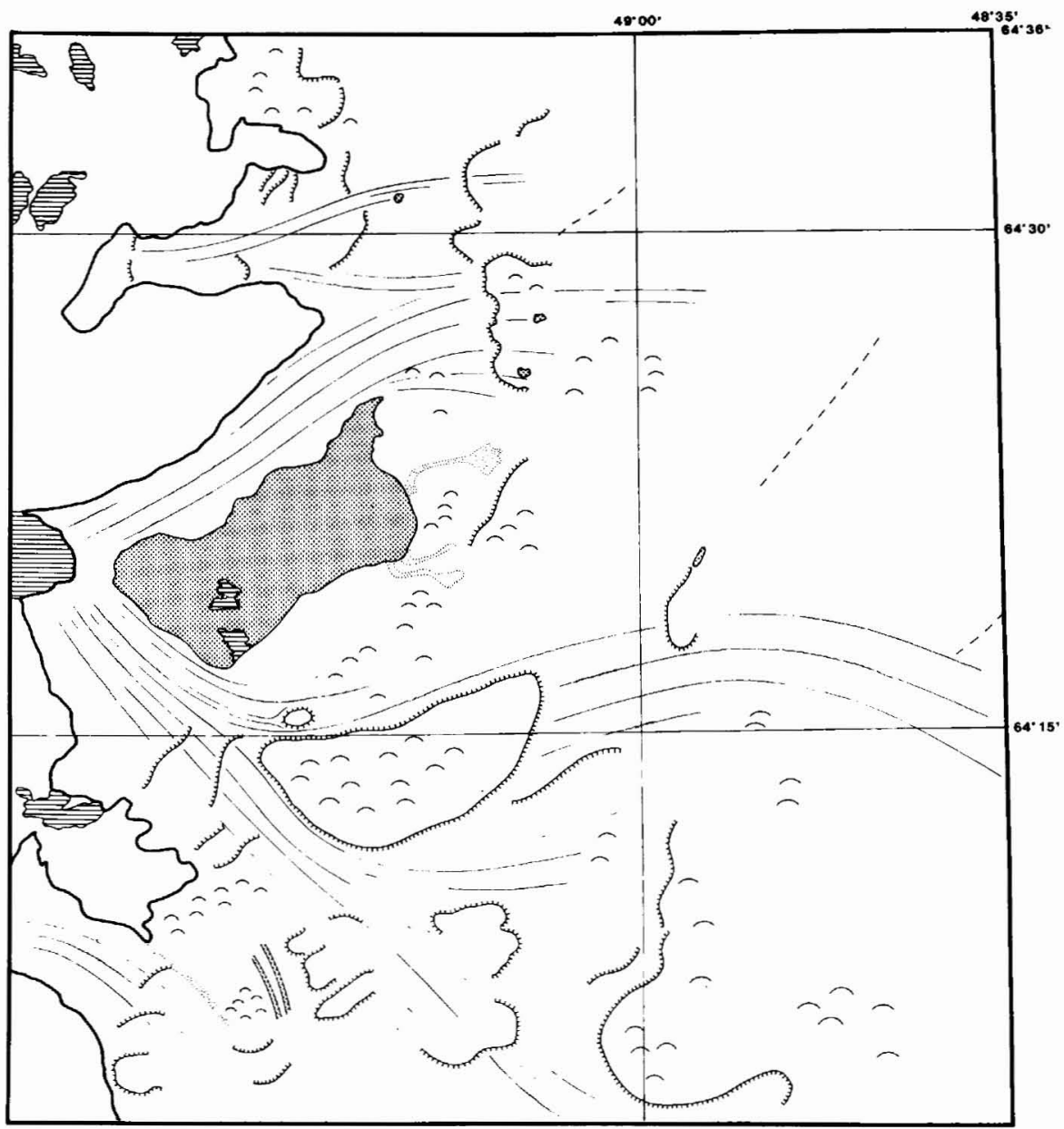

Scale 1:500 000

Lake and ijord Major crevasse field

Fig. 41. Section of surface feature map east of Godthåb. 
was measured in snowpits and by depth soundings at the stakes. The transient and annual balances are shown in fig. 40 . From the curves it can be seen that the annual equilibrium line was at approximately $1000 \mathrm{~m}$ above sea level.

\section{Mapping programme}

Detailed photogrammetric glacier mapping. A map has been produced covering the ice margin of the Inland Ice and the adjoining ice-free area north-east of Frederikshåb between $62^{\circ} 11^{\prime} \mathrm{N}$ and $62^{\circ} 26^{\prime} \mathrm{N}$ (Weidick \& Thomsen, 1983b). This includes the snouts and lower parts of five outlet glaciers (inventory nos 1BI02001-2, 1BI03001, 1BG03001-2). The plotting was based on vertical aerial photographs from 2 nd July 1964 and the scale is 1:25 000 with contour intervals of $50 \mathrm{~m}$ in the ice-free area and $10 \mathrm{~m}$ on the ice. The map is prepared in accordance with the principles described in Thomsen (1983b).

Mapping of surface features on the Inland Ice. Surface feature maps of the Inland Ice were plotted on the basis of Applicon ink plots on a scale 1:100 000 of digital processed Landsat data. The maps show surface features related to ice and meltwater drainage as well as subtle topographic features related to the subglacial topography. The maps cover the Inland Ice in the inner part of Disko Bugt area between $68^{\circ} 35^{\prime} \mathrm{N}$ to $70^{\circ} 00^{\prime} \mathrm{N}$ and $47^{\circ} 20^{\prime} \mathrm{W}$ to $50^{\circ} 30^{\prime} \mathrm{W}$, and in the Godthåb area between $63^{\circ} 30^{\prime} \mathrm{N}$ to $64^{\circ} 36^{\prime} \mathrm{N}$ and $48^{\circ} 35^{\prime} \mathrm{W}$ to $50^{\circ} 05^{\prime} \mathrm{W}$. The digital image processing is described in Thomsen (1983c, 1983d) and the maps are presented in Thomsen (1983c). A section of the surface feature map from the Godthåb area is shown in fig. 41 .

\section{References}

Thomsen, H. H. 1983a: Glaciologiske undersøgelser ved Pâkitsup ilordlia 1982. Ilulissat/Jakobshavn. Grønlands geol. Unders., Gletscher-hydrol. Meddr 83/3, 24 pp.

Thomsen, H. H. 1983b: A glaciological field and mapping programme in connection with hydropower, West Greenland. Rapp. Grønlands geol. Unders. 115, 102-107.

Thomsen, H. H. 1983c: Satellitdata - et redskab til studier af Indlandsisens randzone i forbindelse med vandkraftundersøgelser. Grønlands geol. Unders., Gletscher-hydrol. Meddr 83/8, 24 pp.

Thomsen, H. H. 1983d: Glaciological applications of Landsat images in connection with hydropower investigations in West Greenland. Proc. EARSel/ESA Symposium on Remote Sensing Applications for Environmental Studies. European Space Agency 188, 133-136.

Weidick, A. \& Olesen, O. B. 1980: Hydrological basins in West Greenland. Rapp. Grønlands geol. Unders. 94, $51 \mathrm{pp}$.

Weidick, A. \& Thomsen, H. H. 1983a: Lokalgletschere og Indlandsisens rand i forbindelse med udnyttelse af vandkraft i bynære bassiner. Grønlands geol. Unders., Gletscher-hydrol. Meddr 83/2, 129 pp.

Weidick, A. \& Thomsen, H. H. 1983b: Glaciologiske undersøgelser. Frederikshåb/Pamiut 1982. Grønlands geol. Unders., Gletscher-hydrol. Meddr 83/6, 46 pp. 